\title{
Artvin Çoruh Üniversitesi Seyitler Yerleşkesinin Güz Dönemi Katı Atık Karakterizasyonu
}

\author{
Kazım Onur Demirarslan ${ }^{1, *}$, Emre Aydın, Mehmet Ali Aydın ${ }^{1}$ \\ ${ }^{1}$ Artvin Çoruh Üniversitesi Mühendislik Fakültesi Çevre Mühendisliği Bölümü, 08100, Artvin. \\ Özet
}

Günümüzde nüfus artışı, kentleşme, endüstrileşme gibi gelişmelere paralel olarak çevresel problemlerde de artış görülmektedir. Sözü edilen bu çevresel problemler arasında katı atıklar tarafindan oluşan hava, su ve toprak kirliliği özellikle dikkatleri üzerlerine çekmektedir. Atık yönetim sistemi uygun bir şekilde yönlendirilmedikçe, yönetimler her yıl katlanarak artan atık yüküyle karşı karşıya kalacaklardır. Meydana gelen bu atıkların yerel yönetimlerce kaynağında toplanarak uygun bir şekilde bertaraf edilmesi gerekmektedir. Evsel katı atıkların yanı sıra ülkemizde kamu binalarında meydana gelen katı atıklar da önemli bir yer oluşturmaktadır. Özellikle okul, üniversite gibi eğitim mekânlarında ekonomik değeri yüksek atıkların oluşması oldukça muhtemeldir. Yapılan bu çalışma da Artvin Çoruh Üniversitesi Seyitler Yerleşkesi'nde meydana gelen katı atıkların nitelikleri incelenmiştir. İnceleme, eğitim ögretimin devam ettiği 19.10.2016 - 14.12.2016 tarihleri arasinda dört noktada yapılmış ve güz dönemini temsil edecek şekilde kurulmuştur. Atık bileșiminin ayrıștırılması așamasında, yerleșke genelinden toplanan atıkların \%42,77'si organik, \%7,23 kağıt, \%6,19 plastik, \%4,37 cam, \%0,39 metal, \%1,09 tekstil, \%37,79 septik kişisel kullanım maddelerinden oluştuğu belirlenmiştir. Çalıșma ile ilerleyen dönemlerde geri dönüşüm odaklı atık yönetim planlamalarının hayata geçirilmesinde zaman, miktar ve atık niteliği ile nasıl değerlendirilebileceği üzerine genel bir fayda sağlaması hedeflenmistir.

\section{Autumn Solid Waste Characterization in the Seyitler Campus of Artvin Çoruh University}

\begin{abstract}
In parallel with the recent developments in population growth, urbanization, industrialization, a rising in environmental problems has also been observed. Among these environmental problems mentioned, air, water and soil pollution caused by solid wastes attract attention in particular. Unless the waste management system is appropriately guided, managements will be faced with exponentially increasing waste load every year. The waste produced should be collected and appropriately disposed by the local governments at the source. In addition to solid waste generated domestically, the solid waste produced in public buildings of our country also constitute an important place. Especially in educational places such as schools and universities, it is highly probable that high economic value wastes are formed. In this study, the qualities of the solid wastes generated in the Seyitler Campus of Artvin Çoruh University were examined. The study was conducted in four locations between 19.10.2016 and 14.12.2016, during the continuation of education to represent the fall semester. In the sortation process of the waste composition, it was determined that the wastes collected from the campus consisted of $42,77 \%$ organic, 7,23 \% paper, 6,19\% plastic, 4,37\% glass and 0,39\% metal, 1,09\% textile, 37,79\% septic personal use. The aim of the study is to provide a general benefit on how the characteristics of time, quantity and waste can be evaluated in carrying out waste management plans in the future by focusing on recycling.
\end{abstract}

\section{Keywords}

Artvin Çoruh University, Seyitler Campus, Solid Waste, Characterization Research

\section{Giriş}

Nüfus artışı ve artan tüketim dünya çapında büyük bir atık oluşumuna neden olmaktadır. Kentleşmenin artmasıyla beraber kaynakların tüketimi, endüstriden evlere kadar tüm aktivitelerde önemli miktarda atık oluşumu görülmekle beraber atık miktar ve çeşitliliğinde de farklılaşmalar görülmekte, kişi başı üretilen atık miktarı da artmaktadır. Ayrıca bilim ve teknolojilerdeki gelişmeler nedeniyle de atıkların hacimleri ve toksisitesinde de artış gözlenmektedir (Karak vd. 2012; Turan vd. 2009; Ağdağ 2009). Gün geçtikçe artan kentsel atık ve bu atığın atık yönetimi sistemi ile uygun şekilde değerlendirilmesi, en azından yerel yönetimler ve teknik çevrelerce en büyük sosyal ve çevresel kaygılardan biri olmuştur.

\footnotetext{
* Sorumlu Yazar: Tel: + 90 (464) 2151040 Faks: +90 (466) 2151057 
Bunun nedeni olarak düzgün yönetilemeyen atıkların çevre üzerine negatif etkileri olan hava, toprak ve su kirliliği doğrudan, hijyen, flora ve fauna kirlenmesi, bunların sonucunda da halk sağlı̆̆ı tehdidi problemlerini doğurmaktadır (Erses Yay 2015). Halk arasında çöp olarak da bilinen kentsel atıkların içerisinde yiyecek atıkları, kartonlar, plastikler, PET ürünleri, tekstil, metaller, ahşap, bebek ve hasta bezleri ile küller yer almaktadır (Tozlu vd. 2016). Katı atık yönetimi kavramı dünyanın farklı bölgelerinde farklı biçimlerde ele alınan küresel bir gerçekliktir. Gelişmiş ekonomilere sahip ülkelerde atık yönetimi üretiminden taşınmasına, geri dönüşümünden nihai bertaraf edilmesine kadar geçen süreçleri kapsamaktadır. Ancak gelişmekte olan ülkelerde teknik, ekonomik ve sosyal sınırlamalar nedeniyle atık yönetim sistemi bazı problemlerle karşılaşmaktadır (Akıncı vd. 2012). Kentsel atık yönetim sistemi karmaşık ve çok yönlü olup birçok disiplinin birlikte hareket etmesini zorunlu kılmaktadır (Guerrero vd. 2013). Başarılı bir atık yönetim sisteminde meydana gelen atıkların miktar ve kompozisyonunun belirlenebilmesi gerekmektedir (Gidarakos vd. 2006). Bu nedenle katı atık yönetim sisteminin düzgün planlanabilmesi için güvenilir atık istatistiklerine ihtiyaç duyulmaktadır (Metin vd. 2003). Söz konusu atık kompozisyonları mevsimlere, hayat standartlarına, demografiye, coğrafik ve bölgesel özelliklere göre değişiklik gösterebilmektedir (Gidarakos vd. 2006). Günümüzde dünyanın birçok bölgesinde katı atıklar içinde ekonomik geri dönüşümü sağlanamayan kısmının bertarafı için vahşi veya düzenli depolama ile yakma gibi teknolojiler kullanılmaktadır. Yakma yoluyla bertaraf sistemi, düzenli depolamanın mekânsal olarak imkânsız olduğu, ekonomik olarak pahalı olacağı durumlarda, her türlü hava kirliliği önlemleri alınmak suretiyle gelişmiş ülkelerce tercih edilmekte, gelişmekte olan ülkelerde ise daha düşük maliyeti nedeniyle sıklıkla vahşi depolama yöntemi kullanılmaktadır (Nas ve Bayram 2008).

Türkiye'de atık yönetim sisteminin önemi yıllar geçtikçe daha iyi anlaşılmaktadır. Türkiye İstatistik Kurumu tarafından yapılan araştırmalar neticesinde hem Türkiye'de hem de çalışma alanı olan Artvin Çoruh Üniversitesi Seyitler Yerleşkesinin bulunduğu Artvin ilindeki atık miktarları kayıt altına alınmıştır. Bu verilere ait grafikler Şekil 1, 2 ve 3' de verilmektedir (URL-1 2017).

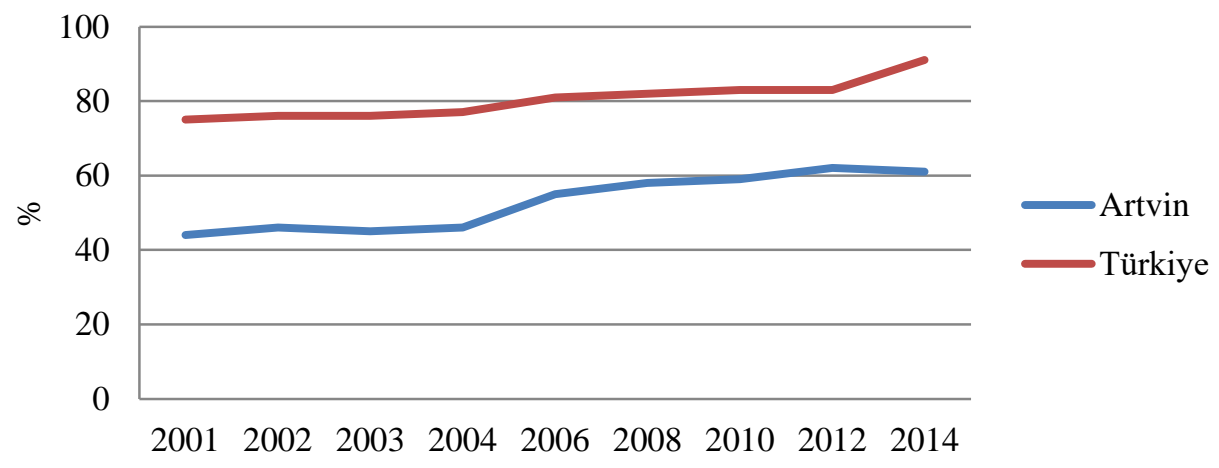

Şekil 1: Türkiye ve Artvin'de Atık Hizmeti Verilen Belediye Nüfusunun Toplam Belediye Nüfusuna Oranı (\%)

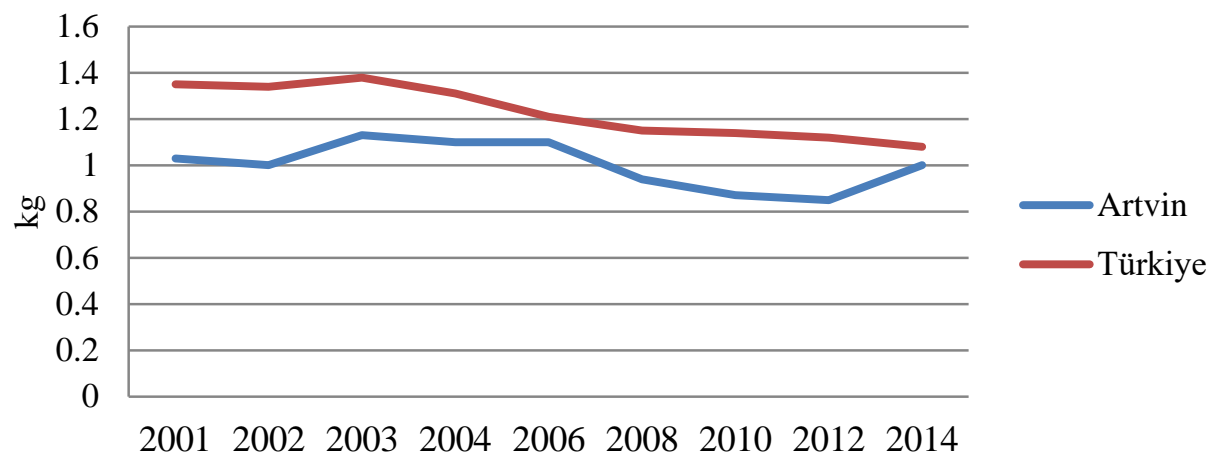

Şekil 2: Kişi Başı Ortalama Belediye Atık Miktarı (Kg/Kişi-Gün)

Şekil 1'e göre atık hizmeti verilen belediye nüfusunun toplam belediye nüfusuna oranının 2001 - 2014 yılları arasında arttığı görülmektedir. 2001 yılında Türkiye'de \%75, Artvin'de \%44 olan bu oran, 2014 yılına gelindiğinde sirasıyla \%91 ve \% 61 'e ulaşmıştır. Şekil 2'de ise kişi başı ortalama belediye atık miktarı görülmektedir. Bu grafikten anlaşılacağı üzere 2001 yılında Türkiye genelinde kişi başı üretilen atık miktarı 1,35 kg/kişi.gün, Artvin'de ise 1,03 kg/kişi.gün olmuştur. 2014 yılında ise sırasıyla 1,08 kg/kişi.gün ile $1 \mathrm{~kg} /$ kişi.gün sonucuna ulaşılmıştır. Atık miktarındaki azalma ekonomik, kültürel ve demografik yapıyla özdeşleştirilebilir. Şekil 3'de görülen grafikte yıllara göre değişen atık miktarları görülmektedir. Her iki grafikte atık miktarları yıllara göre değişim göstermiş, 2014 yılında en yüksek oranına ulaşmıştır. 


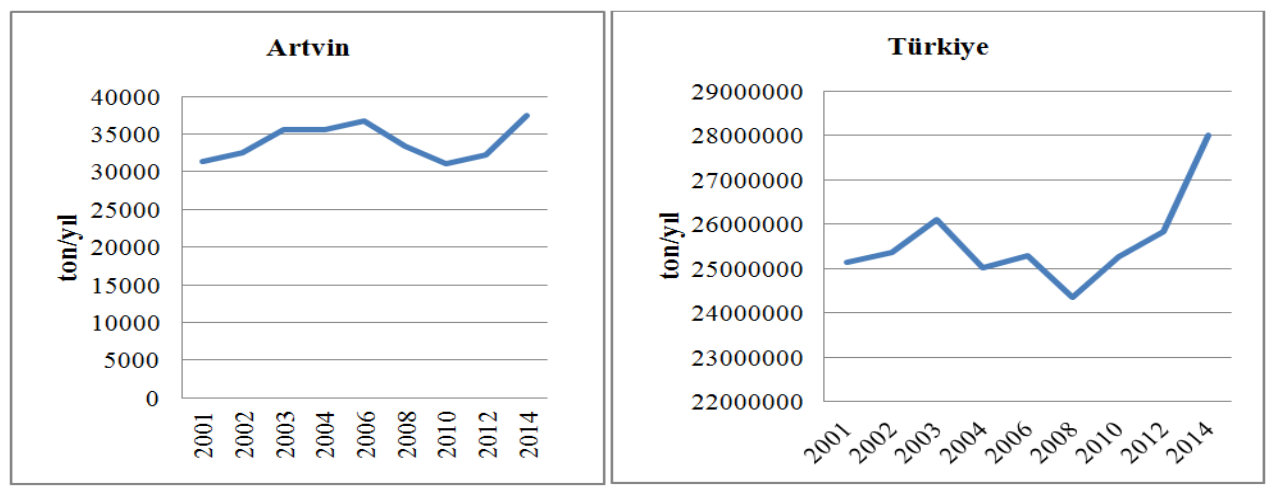

Şekil 3: Türkiye ve Artvin'de yıllara göre atık miktarı

Yapılan bu çalışmada Artvin Çoruh Üniversitesi Seyitler Yerleşkesi'nde 2016 yılı güz döneminde meydana gelen atıkların miktar ve kompozisyonları belirlenmiştir. Elde edilen veriler çerçevesinde yerleşke içerisinde oluşan atıkların özelliklerine göre ayrı toplanmasının uygun olup olmadığına bakılmış ve ileride yapılacak bir atık yönetimi için kaynak olması hedeflenmiştir.

\section{Materyal ve Metot}

Artvin Çoruh Üniversitesi Seyitler Yerleşkesinin bulunduğu Artvin 40,35 ile 41,32 kuzey enlemleri ve 41,07 ile 42,00 doğu boylamları arasında yer alan, $7367 \mathrm{~km}^{2}$ yüzölçümüne sahip Türkiye'nin bir ilidir. Doğusunda Ardahan, batısında Rize, kuzeyinde Gürcistan, güneyinde Erzurum ile komşudur. Kuzey batısında Karadeniz vardır. İlde sanayi sektörü oldukça düşük seviyededir. Sanayi sektöründe faaliyet gösteren işletmeler, daha çok ilin doğal kaynak potansiyelini değerlendirmeye yönelik olarak faaliyette bulunan gıda, maden ve orman ürünleri ağırlıklı bir yapıya sahiptir. Artvin'de herhangi bir organize sanayi bölgesi mevcut değildir. Ancak küçük sanayi siteleri (Merkez, Arhavi, Hopa İlçeleri) mevcuttur (Demirarslan 2016). Artvin il merkezine yaklaşık olarak $12 \mathrm{~km}$ uzaklıkta bulunan Seyitler Yerleşkesi ise 187 dönüm arazi üzerine kurulmuştur. Seyitler Yerleşkesinde Rektörlük, Rektörlüğe bağlı bazı birimler ile Orman Fakültesi, Mühendislik Fakültesi, Fen-Edebiyat Fakültesi, Merkezi Araştırma Laboratuvarı, Sosyal Tesisler ile Sosyal Bilimler Enstitüsü ve Fen Bilimleri Enstitüsü yer almaktadır. Çalışma alanı Şekil 4’te verilmektedir.

Artvin Çoruh Üniversitesi Seyitler Yerleşkesinde öğrenci sayısı olarak Orman Fakültesi 159, Fen Edebiyat Fakültesi 677, Mühendislik Fakültesi 25 olmak üzere toplamda 861 öğrenci, akademisyen ve idari personel sayısı ise 298'dir. Toplamda Seyitler Yerleşkesinde akademisyen, personel ve öğrenci olarak 1159 kişi bulunmaktadır.

Katı atık karakterizasyon çalışması Artvin Çoruh Üniversitesi Seyitler Yerleşkesinde kalorifer dairesi arkasındaki konteyner grubu (2 adet) ve Fen Edebiyat Fakültesi arkasındaki konteyner grubu ( 2 adet) olmak üzere toplamda 4 adet konteyner üzerinde yapılmıştır. Çalışmaya 19.10.2016 tarihinde başlanılmış olup; 15 gün ara ile saat 17.00'de toplamda 5 adet ölçüm yapılmıştır ve ölçümler 14.12.2016 tarihinde sona ermiştir.

Yerleşkede meydana gelen atıklar yukarıda belirtilen konteynerlerde toplanmakta ve her gün saat 21:00-23:00 saatleri arasında Artvin Belediyesi'ne ait araçlarla alınarak kent merkezi dışında bulunan atık sahasına götürülmektedir. Toplanan atıklar hiçbir ayrıştırmaya tabi tutulmadan bertaraf edilmektedir. Yerleşkeye ait atık toplama konteyner örneği Şekil 5'de verilmiştir.

Karakterizasyon çalışmasında Seyitler Yerleşkesinden oluşan 8 atık grubu ön plana çıkmıştır. Bu atıklar sırasıyla septik kişisel kullanım atıkları (tuvalet kâğıdı, peçete, kâğıt bardak (nemlenmiş) vb.), organik atıklar (kantin atıkları, evsel atıklar vb.), kâğıt atıklar (karton, mukavva, gazete, dergi, kitap defter ve yaprakları vb.), plastik atıklar (plastik maddeler, naylon, pet şişe vb.), cam atıklar (cam maddeler, cam şişeler vb.), metal atıklar (demir, saç, alüminyum içecek kutuları vb.), tekstil atıkları (kıyafetler, evsel tekstil parçaları vb.), tehlikeli olabilecek kimyasal atıkları (kartuş, toner, tehlikeli laboratuvar atıkları vb.)' temsil etmektedir.

Katı atık karakterizasyonu için, dijital tartı, sabit hacim kabı $(1 \mathrm{~m} \times 1 \mathrm{~m} \times 1 \mathrm{~m}$ veya $1 \mathrm{~m} \times 1 \mathrm{~m} \times 0,5 \mathrm{~m})$, plastik örtü $(5 \mathrm{~m}$ x 10m), plastik veya metal kap (katı atık bileşen sayısına göre), kürek, tırmık, süpürge, eldiven, maske, çizme, baret, gözlük gibi malzemeler kullanılmıştır.

$5 \mathrm{~m}$ x 10m ebatlarında kalın bir plastik örtü düz bir zemin üzerine serilmiş, dijital tartı, sınıflandırma için kullanılacak kaplar ve sabit hacim kabı yerleş̧irilmiş̧tir. Sabit hacim kabı; $1 \mathrm{~m}$ x $1 \mathrm{~m}$ x 0,5m ölçülerindeki altı ve üstü açık, kulplu, numune almak için kullanılan kaptır. Atık karakterizasyonu çalışmasında, alınan numuneler bileşenlerine göre ayrı ayrı kaplara konduktan sonra kapların öncelikle dolu, ardından boş tartımları alınmıştır. Daha sonra net tartımlardan, bileşenlerin toplam atık içerisindeki \% oranlarına geçilmiştir (Öztürk vd. 2015). 


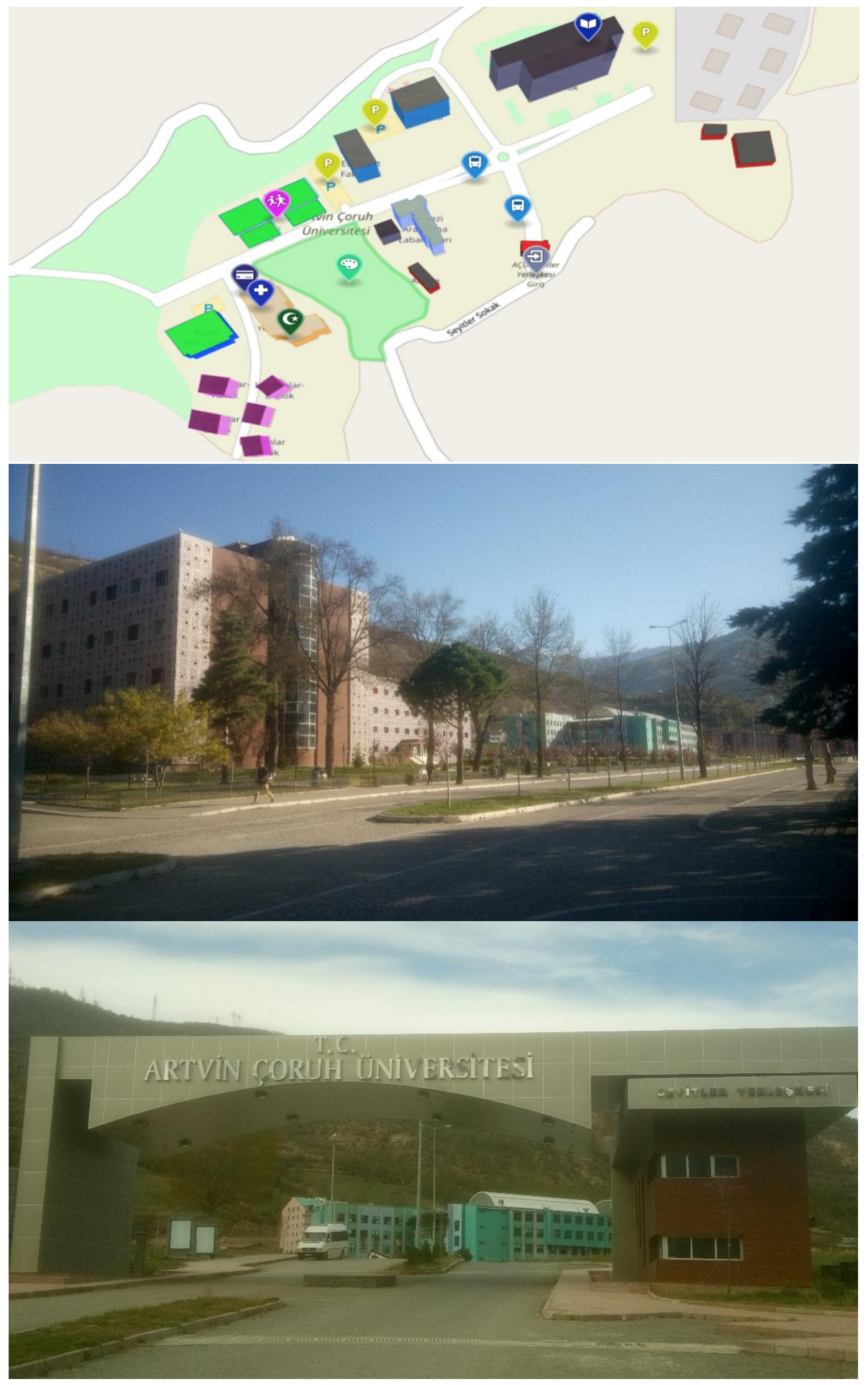

Şekil 4: Artvin Çoruh Üniversitesi Seyitler Yerleşkesi 


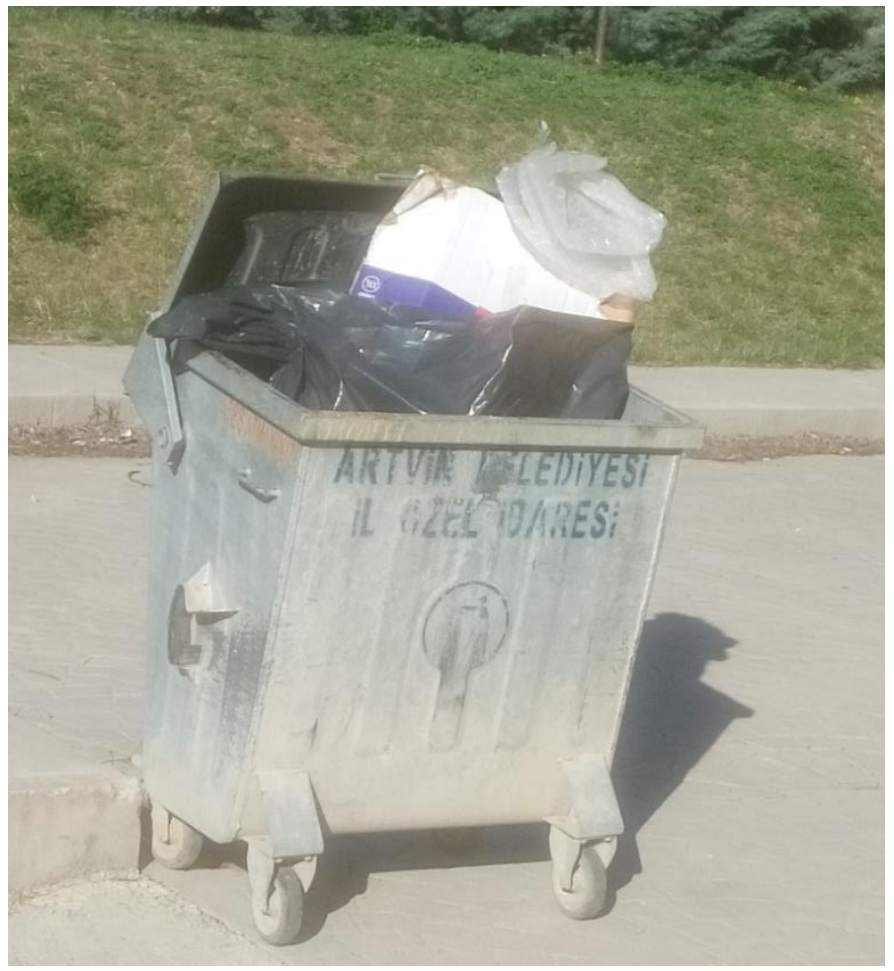

Şekil 5: Yerleşke içi atık toplama konteynerleri

\section{Bulgular}

Yapılan bu karakterizasyon çalışmasında yerleşke içerisinde bulunan 4 adet konteynerden atık örnekleri alınmıştır. Örnekleme işlemine 19.10.2016 - 14.12.2016 tarihleri arasında 15 gün ara ile devam edilmiş ve saat 17.00'de yapılmıştır. Bu saat yerleşkedeki tüm atıkların toplanarak konteynerlere götürüldüğü zamandır ve tüm yerleşkeyi, bu tarih aralıkları ise tüm öğrenci ve personelin yoğun olarak bulunduğu güz dönemini temsil etmektedir. Karakterizasyon çalışmasında, septik kişisel kullanım atıkları, organik atıklar, kâğıt atıklar, plastik, cam, metal, tekstil ve tehlikeli olabilecek kimyasal atıklar olmak üzere 8 atık incelenmiştir. Atıkların yüzde miktarlarını gösteren grafikler Şekil 6, 7, 8, 9, 10 ve 11'de verilmektedir.

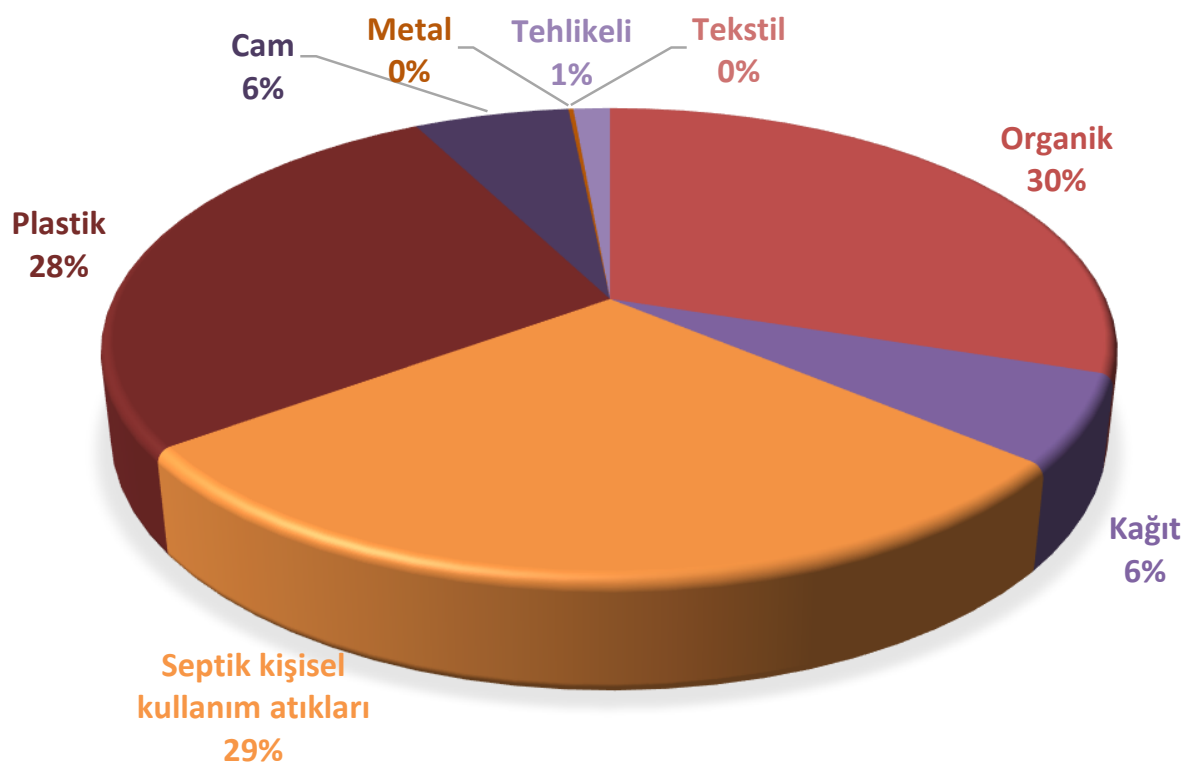

Şekil 6: Birinci atık karakterizasyon çalışması (19/10/2016) 


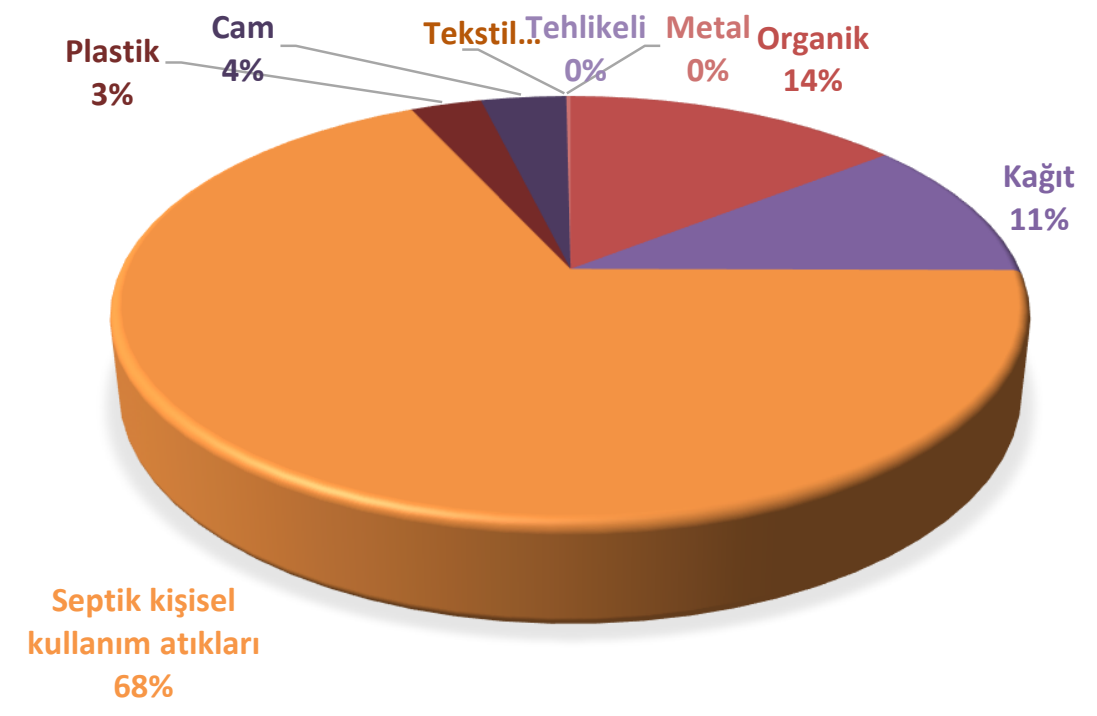

Şekil 7: Ikinci atık karakterizasyon çalışması (02/11/2016)

Yapılan ilk karakterizasyon çalışmasını gösteren Şekil 6 incelendiğinde, organik atıkların \%30 oranında olduğu görülmektedir. Bu atıkları \% 29 ile septik kişisel kullanım türü atıklar izlemektedir. İlk hafta yapılan bu karakterizasyon çalışmasında plastik atıkların diğer haftalara göre daha fazla olduğu (\%28) anlaşılmıştır. Karakterizasyon çalışmasının yapıldığı gün özellikle PET su şş̧elerinin fazlalığı dikkat çekmiştir. Ofislerden ve sınıflardan kaynaklı kağıt atık miktarı ise \%6' dır. Cam atıkların ise kâğıt atıkları gibi \% 6 oranında olduğu görülebilmektedir. Metal atıkların ise hiç görülmediği bu karakterizasyonda ofislerden kaynaklı toner ve flüoresan ampuller gibi tehlikeli atıkların oranı ise \% 1 'dir.

Şekil 7'de verilen ikinci atık karakterizasyon çalışmasına ait verilerden septik kişisel kullanım atıkları \%68 ile en fazla atık türü olduğu anlaşılmaktadır. Bu duruma da o gün hava şartlarının soğuk ve yağmurlu olması olarak yorumlanabilir. Havanın yağışlı olduğu günde kâğıt havlu ve tuvalet kâğıdı gibi maddelerin kullanımı artmıştır. 02/11/2016 tarihli karakterizasyon çalışmasında organik atıklarda oldukça belirgin bir düşüş gözlemlenmiş olup bu duruma ara sınavların yaklaşması nedeniyle öğrencilerin sosyal mekanlarda daha az zaman geçirmesi olarak açıklanabilmektedir. Bu durumun sonucu olarak kâğıt atıklarda gözle görülür bir artış olmuştur (\%11). Yine aynı tarihte yapılan bu çalışmada cam \% 4 , plastik ise \% 3 olarak belirlenmiş, metal ve tehlikeli atığa ise rastlanmamıştır. Metal atıklara rastlanılmamasının sebebi ise havaların soğumasıyla birlikte soğuk tüketilen alüminyum kutulardaki içeceklerin tüketiminin azalması söylenebilir.

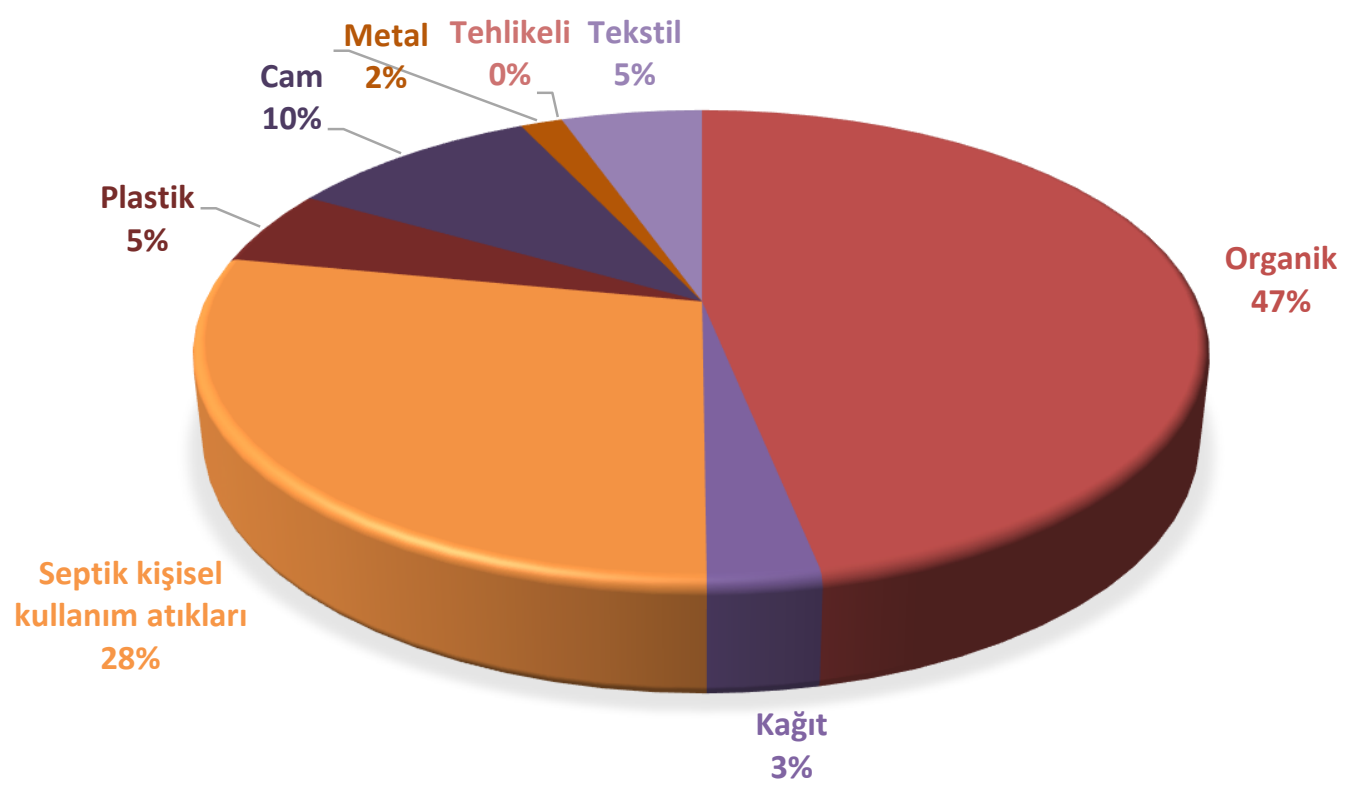

Şekil 8: Üçüncü atık karakterizasyon çalışması (16/11/2016) 


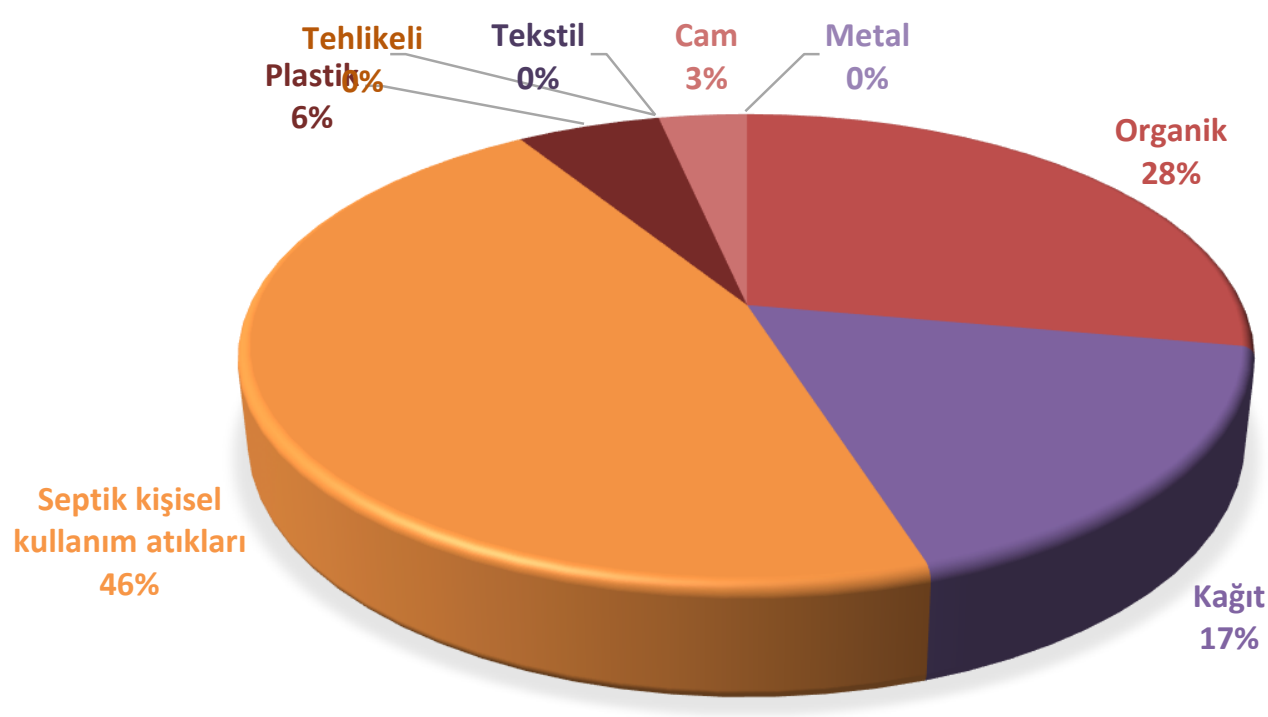

Şekil 9: Dördüncü atık karakterizasyon çalışması (30/11/2016)

Şekil 8'de 16/11/2016 tarihinde yapılan atık karakterizasyon çalışmasının sonucu verilmektedir. Grafiğe göre organik atıkların oranı \%47 ile ilk sıradadır. Septik kişisel kullanım atıkları \% 28, cam \%10 ve plastik \% 5 olarak belirlenmiş bu çalışmada tekstil atıklarına da rastlanmıştır (\%5). Ancak bu tekstil atıkları temizlik amacıyla kullanılan bezlerdir. Mevsimsel şartlar nedeniyle de metal atıkları hala en düşük oranda kalmıştır (\%5). Septik kişisel kullanım atıklarının \%46 ile en yüksek sırada olduğu dördüncü atık karakterizasyon çalışmasının bulguları Şekil 9' da verilmektedir. Yine aynı çalışmada organik atıkların düşük seviyede (\%28) olduğu belirlenmiş, kâğıt atıklarda ise diğger çalışmalara göre bir artış olduğu görülmüştür (\%17). Metal atıklara hiç rastlanılmayan bu çalışmada plastikler \% 6 ve cam atıklar \%3 oranındadır. Şekil 10' da yapılan son karakterizasyon çalışmasının sonuçları verilmektedir. Bu çalışmada organik atıklar \% 72, septik kişisel atıklar ise \% 20 olarak bulunmuştur. Kâğıt atıklar \% 4, cam \% 2 ve plastik ise \% 2 oranındadır. Metal atı̆ga ise yine rastlanmamış olması dikkat çekmektedir.

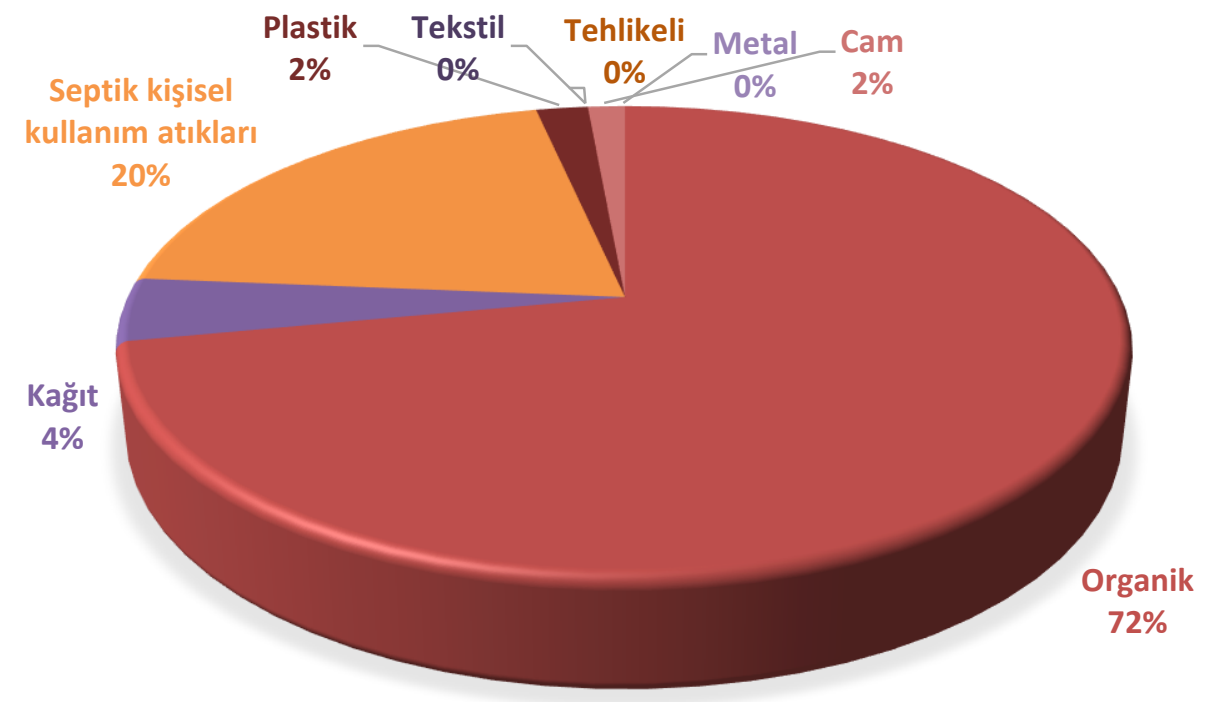

Şekil 10: Beşinci atık karakterizasyonu çalışması (14/12/2016) 


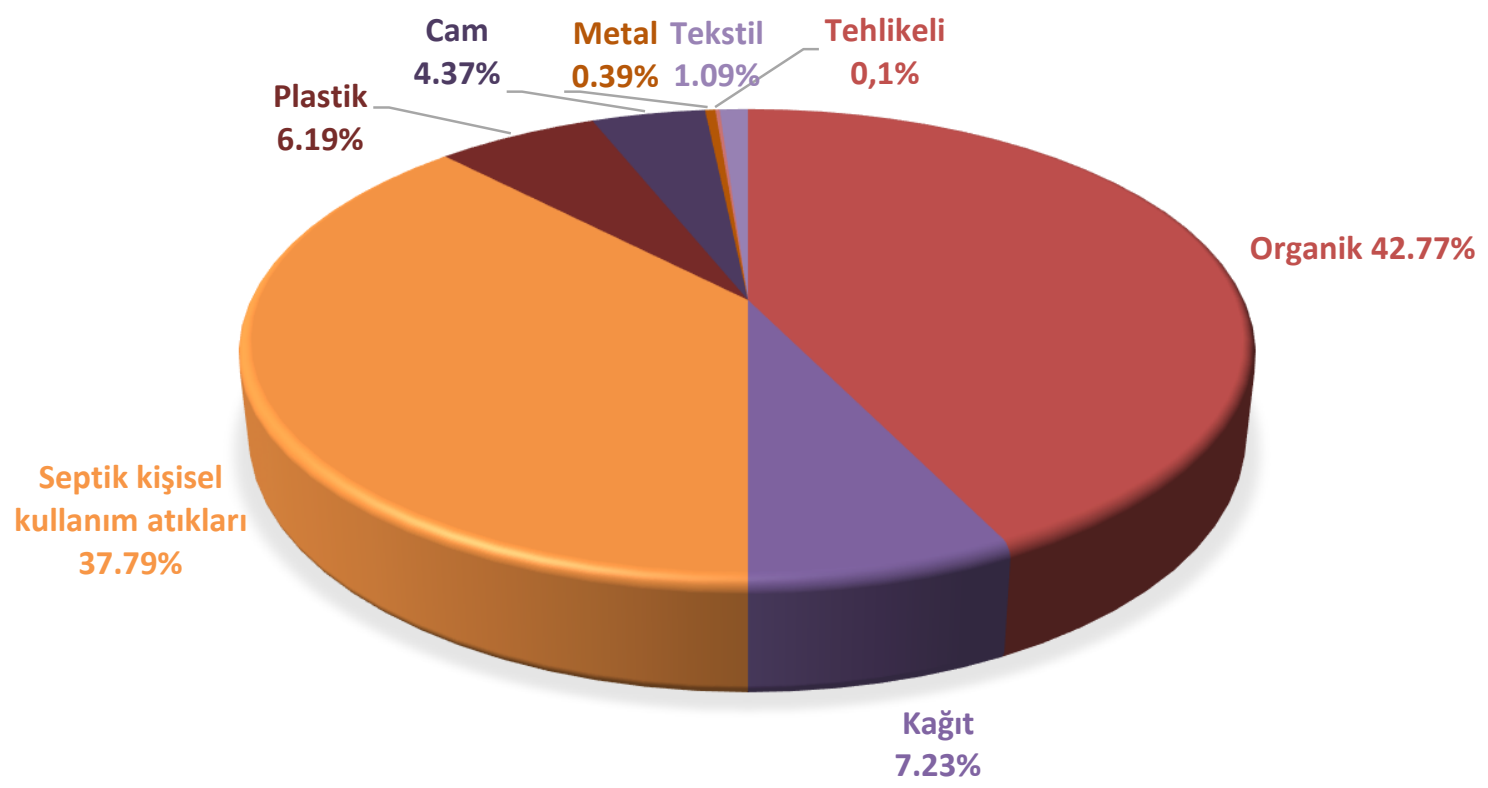

Şekil 11: Genel katı atık karakterizasyonu

Genel atık karakterine bakıldığında 1. sırada organik 2. Sırada septik kişisel kullanım atıkları ve 3. sırada kâğıt atıklar olduğu Şekil 11 ile gösterilmiştir. Sosyal faaliyetlerden oluşan (kantin vb.) atıklardan dolayı organik atıklar ilk sırayı almaktadır. Çoğunlukla fakültelerden ve kantinlerden gelen tuvalet kâğıdı, peçete ve nemlenmiş kâğıt atıklardan dolayı septik kişisel kullanım atıkları da \% 37,79 ile 2. sırayı almaktadır. Konteynerlerdeki geri dönüştürülebilir maddelerden plastik, metal ve camlar kantin ve evsel faaliyetlerden, kâğıt atıklar ise Fakülte ve Rektörlük binaları kaynaklı idari ve eğitim faaliyetlerinden kaynaklanmaktadır ve bunların miktarı \% 18 ile azımsanmayacak oranda olup ekonomik kayıplarının ayrıca değerlendirilmesi gerekmektedir. Tekstil atıkları ise temizlik amaçlı kullanılan kumaşlar ve bezlerden kaynaklanmaktadır. Tehlikeli atıklar ise genellikle ofislerden kaynaklanmaktadır ve en az miktara sahip olan atıklardır.

Elde edilen verilerin ortalaması alındığında ve günlük olarak yorumlandığında Tablo 1'deki değerler elde edilmiştir. Ölçüm tarihlerinin aralığı toplamda 55 gündür ve ortalama değerler günlük olarak yorumlandığında Tablo 1 'deki 55 günlük toplam atık verileri hesaplanabilir.

Tablo 1: Atık miktarları

\begin{tabular}{|l|l|l|l|}
\hline Cinsi & Toplam $(\mathbf{k g})$ & Ortalama Günlük $(\mathbf{k g})$ & $\mathbf{5 5}$ Günlük (kg) \\
\hline Organik & 137,78 & 27,55 & 1515,58 \\
\hline Kâğı̆t Atıklar & 23,3 & 4,66 & 256,3 \\
\hline Septik kişisel Kullanım Atıkları & 121,73 & 24,34 & 1339,03 \\
\hline Plastik & 19,95 & 3,99 & 219,45 \\
\hline Cam & 14,08 & 2,816 & 154,88 \\
\hline Metal & 1,27 & 0,254 & 13,97 \\
\hline Tehlikeli & 0,52 & 0,104 & 5,72 \\
\hline Tekstil & 3,51 & 0,702 & 38,61 \\
\hline TOPLAM & 322,14 & 64,42 & 3543,54 \\
\hline
\end{tabular}

Piyasadaki hurda olarak isimlendirilen geri dönüşebilir maddelerin Nisan 2017 tarihli birim fiyatları ile bu nitelikteki atıkların satılması durumunda elde edilecek gelirler Tablo 2'de verilmektedir (URL-2 2017).

Tablo 2'den görüleceği üzere 55 günlük toplam geri dönüşebilir atıklardan elde edilecek kazanç 328,69 TL olduğu anlaşılmaktadır. Ancak bu çalışmanın mevsimlere göre bir sene boyunca yapılması daha sağlıklı verilerin alınmasını sağlayacaktır. Bunun nedeni olarak atık miktar ve çeşitliliğinin mevsimlere göre farklılık göstermesidir. Örneğin ilkbahar ve yaz mevsimlerinde soğuk içecek ihtiyacının artmasından dolayı metal ve plastik atıkların daha fazla olacağı öngörülebilir. 
Tablo 2: Hurda fiyatları ve elde edilecek kazanç miktarı

\begin{tabular}{|l|c|c|}
\hline Hurda Çeşidi & Birim Fiyatı (TL/kg) & Kazanç (TL) \\
\hline Karışı Toplama Kâğıt & 0,35 & 89,70 \\
\hline PET, Plastik & 0,75 & 164,58 \\
\hline Teneke, Alüminyum vs. & 3,11 & 43,44 \\
\hline Cam & 0,2 & 30,97 \\
\hline Toplam & \multicolumn{2}{|c|}{328,69 TL } \\
\hline
\end{tabular}

\section{Tartışma ve Sonuç}

Katı atıklar günümüzde önemli bir çevresel problemlerden biri olmuştur. Bu çalışma ile ileride Artvin Çoruh Üniversitesi ve benzer kamu kurumları genelinde yapılması planlanan atık yönetimi çalışmalarına bir kaynak olması amaçlanmış, ayrıca kentsel atıkların uygun bir şekilde yönetilebilmesi için belediyeler nazarında birer örnek teşkil etmesi planlanmıştır.

Yapılan bu çalışmada Artvin Çoruh Üniversitesi Seyitler Yerleşkesi’nde meydana gelen atıkların karakterizasyonu incelenmiştir. Çalışma 19.10.2016 - 14.12.2016 tarihleri arasında olup 55 günü yani güz dönemini temsil etmektedir.

İlk karakterizasyon çalışmasında, organik atıklar \% 30, septik kişisel kullanım türünden atıklar \% 29, plastik \%28, kâğıt atık \%6, cam atıkların ise kâğıt atıklar gibi \% 6, metal \% 0, tehlikeli atıkların oranı ise \% 1 olarak belirlenmiştir. İkinci atık karakterizasyon çalışmasında septik kişisel kullanım atıkları \%68, organik atıklar \% 14, kâğıt atıklar \% 11 , cam $\% 4$, plastik ise $\% 3$ olarak belirlenmiş, metal ve tehlikeli atığa rastlanmamıştır. Üçüncü karakterizasyon çalışmasının sonucunda organik atıkların oranı \%47, septik kişisel kullanım atıkları \% 28, cam \%10 ve plastik \% 5, kâğıt atık \% 3 olarak belirlenmiş ve ayrıca bu çalışmada tekstil atıklarına da rastlanmıştır (\%5). Mevsimsel şartlar nedeniyle de metal atıkları hala en düşük oranda kalmıştır (\%5). Septik kişisel kullanım atıklarının \%46 ile en yüksek sırada olan dördüncü atık karakterizasyon çalışmasında, organik atıklar \%28, kâğıt atıklar $\% 17$, plastik \% 6, cam \%3 oranında olduğu görülmüştür. Son karakterizasyon çalışmasında ise organik atıklar \% 72, septik kişisel kullanım atıkları ise \% 20 olarak bulunmuştur. Kâğıt atıklar \% 4, cam \% 2 ve plastik ise \% 2 oranındadır. Metal atıklara ise yine rastlanmamıştır.

Elde edilen veriler incelendiğinde \% 42,77 organik atıklar, \% 37,79 septik kişisel kullanım türü atıklar, \% 7,23 kâğıt atık, \% 6,19 plastik, \% 4,37 cam \% 0,39 metal, \% 1,09 tekstil ve son olarak da \% 0,1 tehlikeli atıkların meydana geldiği görülmektedir.

Kâğıt atıklar, cam ile plastik ve metal atıkları da yerleşke içerisinde önemli bir yere sahiptir. Özellikle geri dönüşebilir nitelikteki atıkların ayrı toplanarak ekonomiye kazandırılması sonucunda 55 gün içerisinde toplamda 328,69 TL' lik bir gelir elde edileceği bulunmuştur. Bu miktar özellikle bir yıl ile özdeşleştirildiğinde önemli bir gelir kaynağı olarak öngörülebilir. Ancak böyle bir atık yönetim çalışmasının yapılabilmesi tüm üniversite genelinde (diğer yerleşkeler, sosyal tesisler ve lojmanlar) bir yıllık bir kompozisyon araştırmasını gerektirmektedir. Çalışma sonucunda üniversite sınırları içerisinde öğrenciler ve personel özendirilerek geri dönüşebilir nitelikteki atıkların ayrı toplanması sağlanabilir. Yerleşkeden çıkan bu geri kazanılabilir atıklar ilgili yasa ve yönetmeliklere uygun olarak satılarak elde edilecek kazanç, ihtiyaç sahibi öğrencilere burs amaçlı olarak verilebilir veya oluşturulacak gelir havuzundan belli günlerde öğrencilerle kaynaşma aktivitelerinde, düzenlenecek pikniklerde iaşe bedeli olarak ya da belli zamanlarda çevre bilincini artırmak amaçlı ücretsiz yiyecek ve içecek dağıtımında kullanılabilir. Bunun yanında organik maddeler ise ayrı bir çalışma gerektirmektedir. Organik maddelerin miktarca fazla olması bu atıkların kompostlaştırma ile toprak katkı maddesi olarak kullanımını teşvik edebilir. Meydana gelen kompost ürünleri ise üniversite bünyesinde bulunan araştırma seralarında rahatlıkla değerlendirilebilir.

\section{Kaynaklar}

Ağdağ O.N., (2009), Comparison of old and new municipal solid waste management systems in Denizli, Turkey, Waste Management, 29(1), 456-464.

Akinci G., Guven E.D., Gok G., (2012), Evaluation of waste management options and resource conservation potentials according to the waste characteristics and household income: A case study in Aegean Region, Turkey, Resources, Conservation and Recycling, $58,114-124$.

Demirarslan K.O., (2016), Kentsel gelişmenin hava kalitesi üzerine etkileri ve doğu karadeniz bölgesi, Karadeniz Araştırmaları Dergisi, $52,27-55$.

Erses Yay A.S., (2015), Application of life cycle assessment (LCA) for municipal solid waste management: A case study of Sakarya, Journal of Cleaner Production, 94, 284-293.

Gidarakos E., Havas G., Ntzamilis P., (2006), Municipal solid waste composition determination supporting the integrated solid waste management system in the island of Crete, Waste Management, 26, 668-679.

Guerrero L.A., Maas G., Hogland W., (2013), Solid waste management challenges for cities in developing countries, Waste Management, 33(1), 220-232.

Karak T., Bhagat R.M., Bhattacharyya P., (2012), Municipal solid waste generation, composition, and management: the world scenario, Critical Reviews in Environmental Science and Technology, 42(15), 1509-1630.

Metin E., Eröztürk A., Neyim C., (2003), Solid waste management practices and review of recovery and recycling operations in Turkey, 
Waste Management, 23, 425-432.

Nas S.S., Bayram A., (2008), Municipal solid waste characteristics and management in Gümüşhane, Turkey, Waste Management, 28(12), 2435-2442.

Öztürk İ., Arıkan A.O., Altınbaş M., Alp K., Güven H., (2015), Katı Atık Dönüşüm ve Arıtma Teknolojileri (El Kitabı), Türkiye Belediyeler Birliği, Korza Yayıncılık Basım San. ve Tic. A.Ş., Ankara, 281ss.

Tozlu A., Özahi E., Abuşoğlu A., (2016), Waste to energy technologies for municipal solid waste management in Gaziantep, Renewable and Sustainable Energy Reviews, 54, 809-815.

Turan N.G., Çoruh S., Akdemir A., Ergun O.N., (2009), Municipal solid waste management strategies in Turkey, Waste Management, 29(1), 465-469.

URL-1, (2017), Belediye atık istatistikleri, www.tuik.gov.tr, [Erişim 05 Nisan 2017].

URL-2, (2017), Günlük Hurda Fiyatları, http://hurdafiyatlarim.com/, [Erişim 05 Nisan 2017]. 